\title{
Morphostructural Damage in Food-Spoiling Bacteria due to the Lemon Grass Oil and Its Vapour: SEM, TEM, and AFM Investigations
}

\author{
Amit Kumar Tyagi and Anushree Malik \\ Applied Microbiology Laboratory, Centre for Rural Development and Technology, Indian Institute of Technology Delhi, \\ New Delhi-110 016, India \\ Correspondence should be addressed to Amit Kumar Tyagi, amittyagiiitd@gmail.com
}

Received 24 May 2012; Accepted 26 August 2012

Academic Editor: Edourad Hnawia

Copyright ( $) 2012$ A. K. Tyagi and A. Malik. This is an open access article distributed under the Creative Commons Attribution License, which permits unrestricted use, distribution, and reproduction in any medium, provided the original work is properly cited.

In this study, antimicrobial activity and morphostructural damages due to lemon grass oil (LGO) and its vapour (LGOV) against Escherichia coli strains were investigated. Minimum inhibitory concentration (MIC) and minimum bactericidal concentration (MBC) of LGO were determined by broth-dilution method to be $0.288 \mathrm{mg} / \mathrm{mL}$ and $0.567 \mathrm{mg} / \mathrm{mL}$, respectively. Furthermore, the zone of inhibition $(45 \mathrm{~mm})$ due to the vapour phase antimicrobial efficacy evaluated using disc volatilization assay was compared with that using disc diffusion assay (i.e., $13.5 \mathrm{~mm}$ for the same dose of oil). The morphological and ultrastructural alterations in LGO- and LGOV-treated E. coli cells were studied using scanning electron microscopy (SEM), transmission electron microscopy (TEM), and atomic-force microscopy (AFM). In SEM observation, LGO-treated cells appeared to be aggregated and partially deformed, while LGOV-treated cells lost their turgidity, and the cytoplasmic material completely leaked from the cells. In TEM observation, extensive intracytoplasmic changes and various abnormalities were observed in LGOV-treated cells more than LGOtreated cells. Significant variations in the height and root mean square values of untreated, LGO-, and LGOV-treated E. coli cells were noticed by AFM. Present results indicate that LGO is highly effective against E. coli in vapour phase.

\section{Introduction}

Microbial contamination of food is increasingly becoming a cause of concern for human health [1]. Recent findings indicate that the food-producing animals, improper cultivation, and unhygienic handling at critical stages of food production can represent some of the most important sources for the entry of virulent and sometimes multidrug-resistant E. coli strains in the food chain $[2,3]$. Therefore, there is a continuous need to develop novel antimicrobial agents to minimize the food contamination as well as the threat of further antimicrobial resistance [4]. In this regard, natural antimicrobials such as essential oils have attracted considerable attention due to the increased consumer awareness on the aspects of food quality and safety [5-7].

Although the essential oils have high efficiency against the foodborne pathogen and spoilage microorganisms in liquid phase, this effect in food is only achieved with higher concentrations of essential oils as compared to the MIC in nutrient media $[8,9]$. Hence, in spite of ample research on the use of essential oils, the application in food preservation is yet to be developed due to the adverse impact of higher concentrations on the organoleptic properties [10]. For reducing the sensory effect, one of the alternative approaches may be the use of essential oil in the vapour phase [11]. Essential oil in vapour phase could be highly effective against foodborne pathogens and spoilage bacteria at relatively lower concentrations [12] than the liquid phase, thereby causing minimum effect on organoleptic properties. This would also be amenable to the upcoming MAP or modified atmospheric packaging [13] and nanoencapsulation technology [14].

Lemon grass oil (LGO) is a natural plant extract, whose antimicrobial properties against Candida albicans in liquid as well as in vapour phase have been studied by our group 
[15]. Nevertheless, to establish the antibacterial efficacy as well, detailed knowledge of the effects of LGO and LGOV on bacterial cell structures is very important. However, so far the studies relating to the cellular morphology of bacteria and the subsequent disruption of their integrity as a result of certain chemicals have been performed using scanning electron microscopes and transmission electron microscopes. Atomic force microscopy (AFM) is a powerful tool in microbiology to study the structure and properties of microbial surfaces at the nanometer level under physiological conditions [16]. Since its invention in 1986, AFM has widely been applied in a variety of nanometer scale investigations in biosciences, including imaging of bacteria [17-19]. The advantages of this technique are that the height and size of the observed objects can be measured precisely. Furthermore, the use of AFM allows the direct observation of processes occurring on the surface of living bacteria treated with the antimicrobial compounds [20-22]. Assessment of damage to bacteria by control agents including the morphological changes to Escherichia coli caused by the antibiotic cefodizime [23], and the Staphylococcus aureus response to vancomycin [24], were done by studying antibacterial peptides using AFM [25]. Nevertheless, the use of such powerful techniques in assessing the cell damage induced by essential oils is rarely seen. As of yet, AFM has not been used to examine the mechanism of action of LGO against E. coli.

The aim of the present study is to perform a high resolution investigation on the surface and morphological alterations induced in E. coli cells after exposure to LGO and LGOV. It is envisaged that by employing a battery of imaging techniques like scanning electron microscopy (SEM) and transmission electron microscopy (TEM) along with AFM, interaction of LGO and LGOV with bacterial cell surfaces could be elucidated.

\section{Material and Methods}

2.1. Materials and Bacterial Culture Preparation. LGO was procured from Natural Aromatics Pvt. Td., New Delhi (India) where the steam-distillation method has been used for LGO preparation from lemon grass (Cympobogon citratus). Growth media, DMSO, and Tween 80 were purchased from Himedia and Qualigens, India, respectively, while ethanol and diethyl ether were purchased from Merck, India.

E. coli $\mathrm{DH} 5 \alpha$ and E. coli ATCC 25922 strains collected from the central microbial culture facility, Department of Biotechnology and Biochemical Engineering, Indian Institute of Technology Delhi, New Delhi India, and Himedia Pvt. Ltd. (India), respectively, were grown in Mueller-Hinton broth $(\mathrm{MHB})$ medium at $30^{\circ} \mathrm{C} 24 \mathrm{~h}$ in an orbital shaking incubator (Scigenics India Pvt. Ltd., India) at $180 \mathrm{rpm}$. Cells were harvested by centrifugation, suspended in sterile distilled water, and used immediately.

\subsection{Antimicrobial Assays}

2.2.1. Determination of $M I C$ and $M B C$ by Broth Dilution Method. Minimum inhibitory concentration (MIC) and minimum bactericidal concentration (MBC) of LGO were determined by broth dilution assay [26]. A range of essential oil concentrations $(0.27-18 \mathrm{mg} / \mathrm{mL})$ was prepared in $100 \mathrm{~mL}$ Mueller-Hinton broth (MHB) medium. To enhance oil solubility, Tween 80 was included at a final concentration of $0.05 \%(\mathrm{v} / \mathrm{v})$. Each flask was inoculated with $10^{6} \mathrm{cfu} / \mathrm{mL}$ of each E. coli strain. Flasks containing only Tween 80 (without essential oil) and $\mathrm{MHB}$ were used as control. The flasks were incubated at $30^{\circ} \mathrm{C}$ in an orbital shaking incubator $(180 \mathrm{rpm})$ for $24 \mathrm{~h}$. One $\mathrm{mL}$ of culture was taken from each flask for serial dilution to make the inoculum of $10^{6} \mathrm{cfu} / \mathrm{mL}$ and inoculated on MHA plates at $30^{\circ} \mathrm{C}$ for $24 \mathrm{~h}$. The plates were observed and MIC was determined. Furthermore the flasks having lesser essential oil concentration than MIC level were subcultured four times and inoculated on MHA plate for MBC determination.

2.2.2. Disc Diffusion Method. Disc diffusion method was employed for the determination of antimicrobial activities of the LGO in liquid phase [27]. Briefly, a $100 \mu \mathrm{L}$ portion of each suspension containing approximately $10^{6} \mathrm{cfu} / \mathrm{mL}$ was spread over the surface of the MHA plate and allowed to dry. A paper disc (diameter $6 \mathrm{~mm}$, Sigma-Aldrich, India) was impregnated with $10 \mu \mathrm{L}$ essential oil on each disc and placed on the inoculated plates. These plates, after staying at $4^{\circ} \mathrm{C}$ for $2 \mathrm{~h}$, were incubated at $37^{\circ} \mathrm{C}$ for $24 \mathrm{~h}$ for bacterial growth. The diameters of the inhibition zones were measured in millimetres. Volume of essential oils tested was varied (20, $40 \mu \mathrm{L}$ ) by using an appropriate number of sterile discs.

2.2.3. Disc Volatilization Method. Standard experimental setup as described by [28] was used. Briefly, a $100 \mu \mathrm{L}$ portion of each suspension containing approximately $10^{6} \mathrm{cfu} / \mathrm{mL}$ was spread over the surface of the MHA plate and allowed to dry. A paper disc (diameter $6 \mathrm{~mm}$, Sigma-Aldrich, India) was laid on the inside surface of the upper lid and $10 \mu \mathrm{L}$ essential oil was placed on each disc. The plates inoculated with microorganisms were immediately inverted on top of the lid and sealed with parafilm to prevent leakage of essential oil vapour. Plates were incubated at $30^{\circ} \mathrm{C}$ for $24 \mathrm{~h}$ and the diameter of the resulting inhibition zone in the bacterial lawn was measured. Volume of essential oils tested was varied (20, $40 \mu \mathrm{L}$ ) by using an appropriate number of sterile discs.

\subsection{Preparation of E. coli Sample for Morphological Study.} The E. coli ATCC 25922 cells were incubated for $14 \mathrm{~h}$ in MHB at $30^{\circ} \mathrm{C}$ and $180 \mathrm{rpm}$. The suspension was divided into two portions. In one portion, LGO at MIC level $(0.288 \mathrm{mg} / \mathrm{mL})$ was added and another portion was left untreated as a control. The resuspension was incubated at $30^{\circ} \mathrm{C}$ for $4 \mathrm{~h}$.

For investigating the effect of LGO vapour, $1 \mathrm{~mL}$ of E. coli cell suspension $\left(10^{6}\right.$ cells $\left./ \mathrm{mL}\right)$ was inoculated on an MHA plate and incubated at $30^{\circ} \mathrm{C}$ for $12 \mathrm{~h}$. These Pregrown cells were treated with $\operatorname{LGOV}(0.30 \mathrm{mg} / \mathrm{mL})$ for $4 \mathrm{~h}$. The treated cells were then collected gently with the help of a brush from the petri plate and collected in a separate test tube. All the treated cells were harvested by centrifugation and were prefixed with a $2.5 \%$ glutaraldehyde solution overnight at $4^{\circ} \mathrm{C}$. After this, the cells were again harvested 
by centrifugation and washed three times with $0.1 \mathrm{M}$ sodium phosphate buffer solution ( $\mathrm{pH} 7.2$ ). Now each resuspension was serially dehydrated with $25 \%, 50 \%, 75 \%, 90 \%$, and $100 \%$ ethanol, respectively. Then, cells were dried at "critical point."

For SEM, a thin film of cells was smeared on a silver stub. The samples were gold covered by cathodic spraying (Polaron gold). Finally, the morphology of the E. coli cells was observed on a scanning electronic microscope (ZEISS EVO $50)$. The SEM observation was done under the following analytical condition: $\mathrm{EHT}=20.00 \mathrm{kv}$; $\mathrm{WD}=10 \mathrm{~mm}$; signal $A=\mathrm{SE}_{1}$.

For TEM, the pellet was post-fixed in $1 \%$ osmium tetraoxide for $30 \mathrm{~min}$, washed with phosphate buffer solution ( $\mathrm{pH}$ 7.2), serially dehydrated, in ethanol and embedded in Epon-Araldite resin for making the blocks of the cells pellet. Ultra-thin $(50-100 \mathrm{~nm})$ sections of the cells were stained with uranyl acetate and lead citrate and observed under a Philips transmission electron microscope (CM-10) at $100 \mathrm{ev}$ and direct magnification of $50.00 \mathrm{k}$.

The AFM images were taken employing the Veeco Metrology Group nanoscope IIIa operating in contact mode. In this mode of operation, a silicon nitrite tip with a force constant of $0.58 \mathrm{~N} / \mathrm{m}$ was used. For AFM mounting of $E$. coli cells, glass substrates were employed. Ten micro-litres of each LGO-treated, LGOV-treated and untreated E. coli cell suspension was mounted on a glass substrate. After airdrying, the cells were imaged in air with AFM in tapping mode.

2.4. Statistical Analyses. All the experiments were done in triplicate and the data presented here represents the mean of three replicates. Data related to the zone of inhibition were subjected to analysis of variance (one-way ANOVA) in Duncan's multiple range test using SPSS (version 10) statistical software. The differences with $P<0.05$ were considered significant.

\section{Results and Discussion}

\subsection{Antimicrobial Assays}

3.1.1. Determination of MIC and MBC of LGO against E. coli. MIC of the LGO was determined against E. coli. The oil exhibited concentration-dependent inhibition of growth. A $0.288 \mathrm{mg} / \mathrm{mL}$ concentration of LGO was enough for complete growth inhibition of both E. coli strains. Minimum bactericidal concentration (MBC) is defined as the lowest concentration of oil resulting in the death of $99.9 \%$ of the inoculum (Burt, 2004). MBC of LGO for both E. coli strains was $0.567 \mathrm{mg} / \mathrm{mL}$. In our previous studies, we observed that LGO had strongest antimicrobial activity against $C$. albicans and P. fluorescens as compared to mentha (Mentha piperita) and eucalyptus (Eucalyptus globulus) essential oils. The MIC of LGO against Candida albicans [15] was also similar $(288 \mathrm{mg} / \mathrm{L})$ to the present study while that against Pseudomonas fluorescens [29] was higher $(567 \mathrm{mg} / \mathrm{L})$. The MIC of E. globulus oil for E. coli DH5 $\alpha$ and E. coli ATCC 25922 was several times higher $(4.5 \mathrm{mg} / \mathrm{L})$ than LGO [11].
Table 1 shows the MIC of Cymbopogon sp. oil and its constituents as reported by other authors [30-34] for different strains of $E$. coli. As is evident from this table, the MIC of different species of Cymbopogon sp. was found to vary from $0.12 \%$ to $0.8 \%$. Hence, the MIC for LGO obtained in the present study $(0.032 \%)$ is substantially lower than that reported earlier. Also, the MIC of LGO constituents such as Limonene, Linalool, $\alpha$-pinene, and $\beta$-pinene against the same strain of E. coli used in the present study (ATCC 25922) was reported to vary from $1.25 \mathrm{mg} / \mathrm{mL}$ to $20 \mathrm{mg} / \mathrm{mL}$ in the previous study [32]. Nevertheless, the MIC of one of the major and active component of LGO, that is, geraniol, has been reported to be quite low $(20 \mu \mathrm{g} / \mathrm{mL})$ for certain $E$. coli strains [33]. This is in agreement with the previous reports stating that acyclic $\alpha, \beta$-unsaturated monoterpene aldehydes geranial and neral possess the most significant antimicrobial activity among the LGO constituents. The above discussion indicates that there is a great potential for LGO to be utilized as an antmicrobial or food preservative agent.

3.1.2. Zone of Inhibition due to the LGO and LGOV. Comparison of the antibacterial activity of LGO (through Disc diffusion method) and LGOV (through Disc volatilization method) yielded interesting results. When E. coli cells were exposed to the same concentration of LGO and LGOV $(20 \mu \mathrm{L})$, the resulting zone of inhibition was found to be $13.5 \mathrm{~mm}$ and $44 \mathrm{~mm}$, respectively. Similarly, at $40 \mu \mathrm{L}$ concentration also the inhibition zone due to vapours was significantly higher than that produced by the oil (Figure 1). These results show that LGOV exerted significantly higher antibacterial activity as compared to the LGO in liquid phase at the same concentration.

Inouye et al. [35] studied the vapour phase antimicrobial activity of 72 essential oils. They found that some oils showed weak contact activity by the agar diffusion assay but strong vapour activity by the box vapour assay. However, they observed no difference in activity between the agar diffusion assay and box vapor assay for LGO. On the other hand, Suhr and Nielsen [36] reported that LGO-containing citral was most effective when added as volatiles as compared to direct contact assay. Comparing the present results with our previous reports, it is seen that the same concentration of the LGOV $(20 \mu \mathrm{L})$ produced $44 \mathrm{~mm}$ zone of inhibition in E. coli strains while producing $80 \mathrm{~mm}$ in C. albicans [15] and $26 \mathrm{~mm}$ in P. fluorescens [29]. Nevertheless, it is evident that in all the cases, LGO produced smaller inhibition zones as compared to LGOV, thus establishing the superior performance of the latter. This can be attributed to variation in chemical composition as well as mode of action of LGO and LGOV. Based on our previous investigations [15, 37] wherein the chemical composition of LGO and LGOV was analyzed by GC-MS and SPME-GCMS, respectively, it can be stated that both of them contained the oxygenated monoterpenes dominated by citral. Nevertheless, in the vapour phase certain other constituents such as limonene were also enriched. It is possible that these monoterpenes had better diffusibility in the gaseous phase as compared to the liquid oil phase [38]. To further differentiate the effect 
TABLE 1: Minimum inhibitory concentration (MIC) of Cymbopogon essential oils and their active components against E. coli.

\begin{tabular}{|c|c|c|c|c|}
\hline S. no. & $\begin{array}{c}\text { Antimicrobial } \\
\text { compound/essential } \\
\text { oil }\end{array}$ & E. coli strain & MIC & Reference \\
\hline (1) & Cymbopogon citratus & - & $0.12 \%$ & {$[30]$} \\
\hline (2) & Cymbopogon citratus & LMG 8223 & $>0.8 \%$ & \multirow{4}{*}[31]{} \\
\hline (3) & $\begin{array}{c}\text { Cymbopogon } \\
\text { martinii }\end{array}$ & LMG 8223 & $0.2 \%$ & \\
\hline (4) & Cymbopogon nardus & LMG 8223 & $>0.8 \%$ & \\
\hline (5) & $\begin{array}{l}\text { Cymbopogon } \\
\text { winterianus }\end{array}$ & LMG 8223 & $>0.8 \%$ & \\
\hline (6) & Limonene & ATCC 25922 & $>20 \mathrm{mg} / \mathrm{mL}$ & \multirow{4}{*}[32]{} \\
\hline (7) & Linalool & ATCC 25922 & $1.25 \mathrm{mg} / \mathrm{mL}$ & \\
\hline (8) & $\alpha$-pinene & ATCC 25922 & $2.0 \mathrm{mg} / \mathrm{mL}$ & \\
\hline (9) & $\beta$-pinene & ATCC 25922 & $9.75 \mathrm{mg} / \mathrm{mL}$ & \\
\hline (10) & Geraniol & ETEC 5041-1 & $20 \mu \mathrm{g} / \mathrm{mL}$ & \multirow{2}{*}[33]{} \\
\hline (11) & Geranyl acetate & ETEC 5041-1 & $0.5 \mathrm{mg} / \mathrm{mL}$ & \\
\hline (12) & $\beta$-pinene & ATCC 13706 & $2.5 \mathrm{mg} / \mathrm{mL}$ & \multirow{2}{*}[34]{} \\
\hline (13) & Caryophyllene & ATCC 13706 & $0.625 \mathrm{mg} / \mathrm{mL}$ & \\
\hline
\end{tabular}

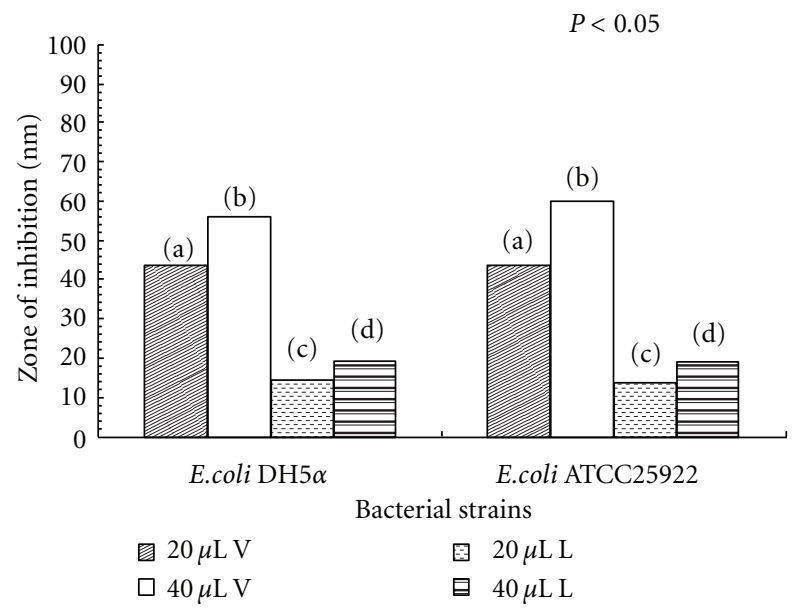

Figure 1: Zone of inhibition due to lemon grass oil (L) and lemon grass oil vapours $(\mathrm{V})$ at different concentrations $(20 \mu \mathrm{L}$ and $40 \mu \mathrm{L})$ The bar of treatment followed by the same letter did not differ significantly by Duncan's multiple range test (DMRT, $P<0.05$ ); LSD, least significant difference by ANOVA.

of LGO and LGOV on cell morphology and ultrastructure, SEM, TEM, and AFM observations were done.

\subsection{Morphological Alteration of E. coli}

3.2.1. Scanning Electron Microscope (SEM) Observation. Bacterial cells treated with LGO at MIC level underwent considerable morphological alterations in comparison to the control when observed by a scanning electron microscope (Figure 2). Control E. coli cells appeared intact, rod shaped, separated from each other, turgid, and complete with smooth surface (Figure $2(\mathrm{a}))$ while the LGO- $(0.288 \mathrm{mg} / \mathrm{mL})$ treated cells appeared to be aggregated and partially deformed
(Figure 2(b)). It seems that the cytoplasmic material of the bacterial cells had leaked and the aggregate cells appeared as sludge (Figure 2(b)). Similar observations indicating the aggregation of bacterial cells as a stress response upon exposure to antimicrobial compounds have been reported earlier [39]. Devi et al. [40] observed the effect of eugenol (clove essential oil) on Salmonella typhi cell surface by SEM, where the eugenol-treated bacterial cells showed deformation in their surface. The authors also visualized disruption of the bacterial membrane and a complete loss of membrane integrity by treatment with $1 \%(\mathrm{v} / \mathrm{v})$ eugenol. Park et al. [41] noticed that citral, which is one of the major constituent of LGO [15] induced shrinkage and partial distortion of Trichophyton mentagrophytes hyphae at a very low concentration $(0.09 \mathrm{mg} / \mathrm{mL})$.

When E. coli was exposed to LGOV, the cells were completely destroyed (Figure 2(c)). The SEM pictures clearly reveal that cells lost the turgidity and the cytoplasmic material completely leaked from the cells. In fact, only the ghost cells were left (shown by arrows) with apparent cellular debris (Figure 2(c)). Such extensive destruction of the cells is rarely demonstrated. Braga and Ricci [42] noticed such flattening and emptying in E. coli cells at Supra-MIC levels of the antimicrobial agent cefodizime. Da-Silva and Teschke, [43] showed that cells were lysed and only the "footprints" of lysed bacteria could be observed through AFM after $30 \mathrm{~min}$ incubation with antimicrobial peptide (PGLa). Sondi and Salopek-Sondi [44] observed that E. coli cells treated with silver nano-particles showed the formation of "pits" in their cell walls. LGOV evoked extensive cell damage similar to that observed with other established antimicrobial agents. Furthermore, the SEM micrographs confirmed the higher efficacy of LGOV as compared to LGO in liquid phase.

\subsubsection{Transmission Electron Microscope (TEM) Observation.} Further evidence of antibacterial potential of LGO and LGOV has been obtained by TEM study. Untreated cells were studied as a control to ensure that the observed differences between control and the treated bacterial cells were indeed due to the effect of LGO/LGOV and not to the preparation method.

TEM photomicrographs of untreated E. coli cells shows a regular outlined cell wall, plasmalemma lying closely to the cell wall, and some dense bodies regularly distributed over the cytoplasm (Figure 3(a)). Electron microscopy revealed that some of the oil-treated cells still retained a cell wall structure similar to untreated cells; however, in the majority of the cells, cell wall thickness varied and occasionally it appeared disrupted (Figure 3(b)). Extensive internal damage and a wide range of abnormalities were observed in the vapour-treated cells (Figure 3(c)). As shown in Figure 3, plasmalemma was damaged and became irregular in the treated cells (Figure 3(c)). Periplasmic space was altered and it became larger and irregular. Intracytoplasmic changes were noticed and the cytoplasm appeared very dense at certain locations and hence unsymmetrically distributed in the cell (Figure 3(c)). Mostly, coagulated material accumulated close to the cell wall and near the apical ends (Figure 3(c)). At certain locations, the cell envelope was damaged (Figure 3(c)) 


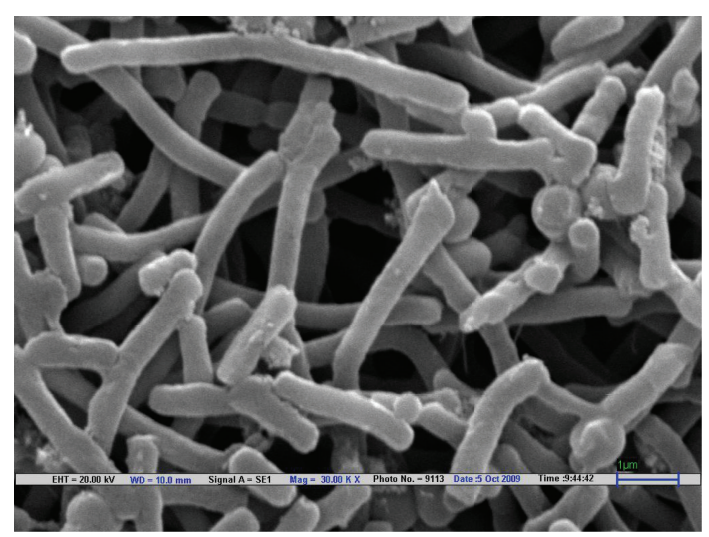

(a)

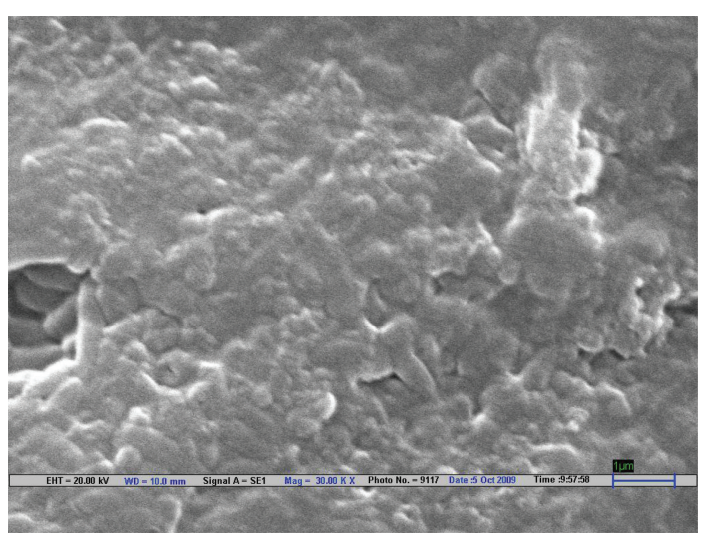

(b)

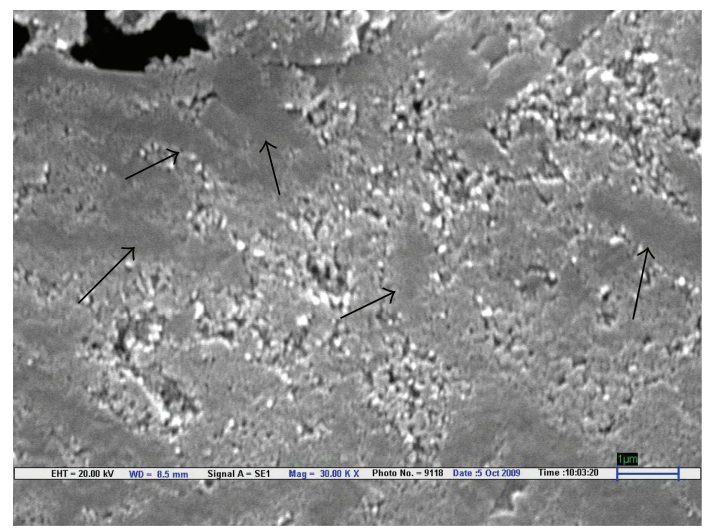

(c)

Figure 2: Scanning electron micrographs of untreated and treated E. coli cells. (a) Untreated cells with normal smooth surfaces $(\times 30.00 \mathrm{~K})$. (b) Shrunken, aggregated, and partially deformed LGO-treated cells $(\times 30.00 \mathrm{~K})$. (c) Completely destroyed and ruptured LGOV-treated cells $(\times 30.00 \mathrm{~K})$.

and the leakage of intracellular contents and emptying of the cells was evident. This can also result from alteration in membrane permeability leading to draining out of the inner contents while the main structure of the outer membrane still remains intact. Such observations were earlier recorded by Yi et al. [45] that tea-Polyphenols- (TP, $0.75 \mathrm{mg} / \mathrm{mL}$ ) treated Pseudomonas aeruginosa showed alteration in the integrity of the outer membrane (OM) and disruption of cell walls. Both the $\mathrm{OM}$ an inner membrane (IM) permeation was demonstrated by increased fluorescence of the NPN (1-N-phenyl-naphthylamine) probe and the 4-methylumbelliferone, respectively, implying NPN uptake into cells through the $\mathrm{OM}$ and $\beta$-galactosidase release through the IM. This means that the TP damaged the OM and IM. However, optical density values at $260 \mathrm{~nm}$ generated little change in TP-treated samples, indicating that no large molecules, such as DNA and RNA, were released and the main structure of the bacterial membrane was still intact. The electron micrographs of chitosan-treated E. coli cells showed disrupted OM covered by an additional tooth-like layer indicating that the mechanism of the antibacterial activity of chitosan is through membrane damage [46]. Castillo et al. [47] also demonstrated that the antimicrobial action of arginine-based surfactant C3 (CA) 2 preferentially against Gram-negative bacteria (E. coli) is mediated through strong initial binding to the surface lipopolysaccharides and subsequent partitioning into the cell membrane to cause membrane damage, followed by cell death. Bactericidal activity of lipophilic monoterpenes (which are a major constituent of essential oils) is related to their capability to deeply interact with and affect the molecular structure of lipidic bilayers. Cristani et al. [48] have shown that $p$ cymene and carvacrol are more active against the Gramnegative E. coli as they markedly affect membrane lipid composition, taking the place of lipid molecules, and are strongly absorbed by lipidic membranes. On the other hand, antimicrobial activity of terpenes such as thymol, which possesses discrete lipophilic characteristics and a detectable water solubility, may be potentiated by the fact that they can migrate across the aqueous extracellular medium, interact with, and damage lipidic membranes. Since the outer layer of the Gram-negative outer membrane is composed primarily of lipopolysaccharide molecules and forms a hydrophilic permeability barrier providing protection against the effects of highly hydrophobic compounds [49], E. coli may exhibit low sensitivity to the cytotoxic effect of the highly lipophilic 


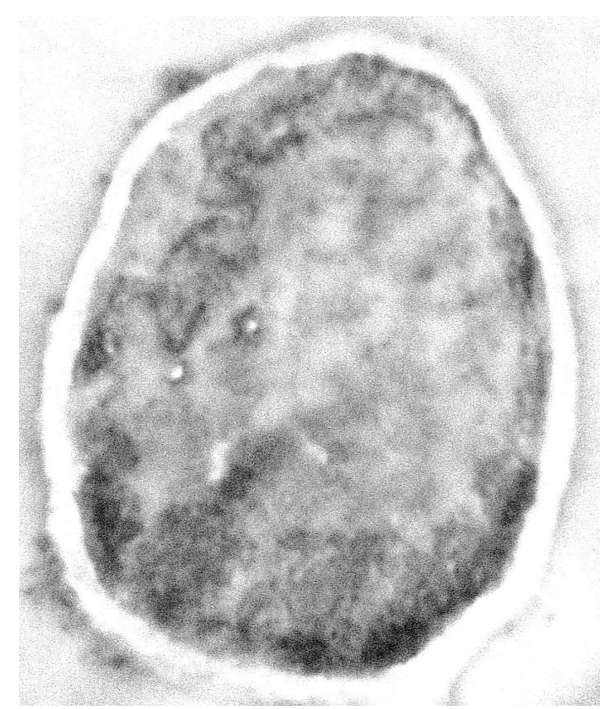

(a)

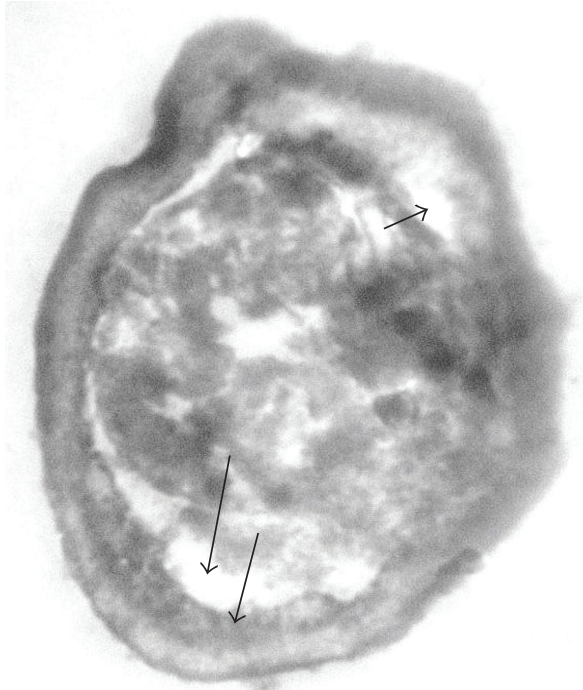

(b)

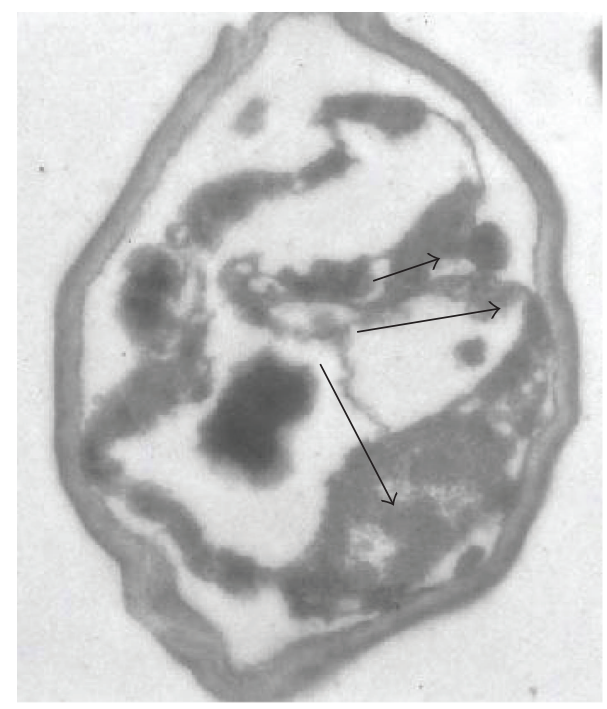

(c)

Figure 3: Transmission electron micrographs of untreated and treated E. coli cells. (a) Untreated E. coli cells having a regular outlined cell wall, plasma lemma lying closely to the cell wall, and regularly distributed cytoplasm. (b) LGO-treated E. coli cells having variable cell wall thickness appearing disrupted and variable periplasmic spaces (shown by arrows). (c) LGOV-treated cells having extensive internal damage, unsymmetrically distributed cytoplasm, and larger and irregular periplasmic spaces (shown by arrows).

monoterpenes. Nevertheless, in the present study E. coli was found to be highly susceptible to low concentrations of LGOV as well as LGO. This could be attributed to the presence of significant amounts of citral both in LGO oil as well as the vapour $[15,37]$. Strong antimicrobial properties of citral are already well documented. Among the four terpenes (citral, eugenol, $\alpha$-terpineol, and nerolidol) tested in the antifungal assay against Trichophyton mentagrophytes, Park et al. [41] noticed the lowest MIC for citral. Furthermore, the authors also noticed extensive and irreversible cell membrane and organelles damage by exposure to $0.2 \mathrm{mg} / \mathrm{mL}$ citral through SEM and TEM observations while for other terpenes such damage was observed at much higher concentrations. The higher potency of the aldehyde (citral) is related to its higher lipophilicity enhancing its interaction and thereby inducing higher membrane damage.

Based on the TEM observations and above discussion, it can be concluded that whilst the cell envelop was damaged at certain locations in the-LGOV-treated cells, the overall boundary of the damaged cells was retained. This indicates that the cell outline was probably maintained but the cells collapsed and turgidity was lost due to leakage of the cytoplasm. This correlates well with the ghost cells or footprints (boundaries intact but height flattened) of the cells observed in the SEM of the vapour-treated cells. To confirm this hypothesis, more detailed investigations are needed that can reflect upon the third dimension, that is, the height and roughness of the cells. 
3.2.3. Atomic Force Microscope (AFM) Observation. AFM of treated and untreated $E$. coli cells also show the evidences of change in morphology due to the antibacterial activity of the LGO and LGOV that corroborates with the SEM and TEM results. Significant variations in the height of the $E$. coli cells from the glass surface have been recorded. The height of untreated, LGO-treated and LGOV-treated was found to be $450 \mathrm{~nm}$ (Figure 4(d)), $14 \mathrm{~nm}$ (Figure 4(e)), and $7 \mathrm{~nm}$ (Figure $4(\mathrm{f})$ ), respectively. The shape of the treated cells could be justified with this height measurement. In accordance with the SEM results, the height of LGOtreated shrunken/sludge cells was $14 \mathrm{~nm}$ while the LGOVtreated completely destroyed cells were $7 \mathrm{~nm}$. Furthermore, the differences in surface area of untreated cells, LGO-, and LGOV-treated cells were 201.02\% (Figure 4(a)), 1.58\% (Figure 4(b)), and 3.48\% (Figure 4(c)), respectively. As per SEM observation, the untreated bacterial cells were separated from each other which means that they had higher value/percentage of surface area per unit while LGOtreated cells appeared like the sludge so the difference in surface area per unit was much less (i.e., 1.58\%). In LGOVtreated destroyed cells, the difference in surface area were more (i.e., 3.48\%) than in the LGO-treated cells due to the presence of cellular debris. The three-dimensional structure of the E. coli cells also shows significant differences in the $Z$ axis value which was $1000 \mathrm{~nm} / \mathrm{div}$ (Figure 4(g)), $30 \mathrm{~nm} / \mathrm{div}$ (Figure 4(h)) and $25 \mathrm{~nm} / \operatorname{div}$ (Figure 4(i)) in untreated, LGOtreated and LGOV-treated samples, respectively. A reduction in cell height has also been recorded in the AFM observations of carvacrol [50] and PGLa-treated E. coli cells [43].

Roughness analysis of differently treated $E$. coli cells has been observed with the atomic force microscope (AFM). The root mean square (rms) values of untreated, LGO-treated and LGOV-treated cells were $1.86 \mathrm{~nm}$ (Figure 4(a)), $2.33 \mathrm{~nm}$ (Figure 4(b)), and $3.32 \mathrm{~nm}$ (Figure 4(c)), respectively. This confirms that the effect of volatile compound (vapour phase) on the bacterial cell wall/membrane was more prominent than liquid phase/direct treated bacterial cells. Similar enhancement in the roughness of $E$. coli cells was observed by Da Silva and Teschke, [43] after treatment with PGLa. The roughness at the top surface of PGLa-treated bacterial cells increased substantially from $1 \mathrm{~nm}$ (for untreated bacterium) to $2.25 \pm 0.03 \mathrm{~nm}$. Furthermore, variation in height of the bacterial cell along the body length was observed in the present study (Figure 5) in the LGO- and LGOV-treated cells. By this graphical representation, we can estimate the higher effectivity of LGOV (Figure 5(c)) than LGO (Figure 5(b)) in terms of height versus surface roughness of differently treated cells. Similarly, La Storia et al. [50] noticed an increase in mean roughness in $E$. coli 32 cells from $\approx 1 \mathrm{~nm}$ (for untreated bacterium) to $2.5 \mathrm{~nm}$ in carvacrol treated cells. The authors speculated that the action of carvacrol may render the components of the outer membrane (e.g., proteins and lipids) in Gram-negative bacteria more exposed to the external surface, causing an increase in roughness. In the present study, a more significant increase in roughness coupled with cell lysis and height reductions in LGOVtreated cells indicate that monoterpenes present in the LGOV cause higher damage in the gaseous phase. This could be attributed to better diffusibility and partitioning into membrane structures of bacteria in the gaseous phase [51].

Bacterial cell damage was observed using standard electron microscopy (TEM or SEM) in the past. Subsequently, some studies used AFM to study the antibacterial effect of synthetic antimicrobial compounds. Braga and Ricci, [52] used AFM for investigating the damage to bacterial morphology induced by an antimicrobial agent, cefodizime. Milder damages such as filamentation and bulge formation were observed in E. coli after exposure to sub-MICs of cefodizime while at supra-MIC levels bacterial flattening and emptying was observed. Supra-MICs of cefodizime induced the death of E. coli and led to lysis of the bacterium. Nevertheless, the damage was in terms of a hole on the surface, where the cell wall had disappeared to reveal the fine structure of the underlying cytoplasm, whereas the remaining part of the bacterium seemed to be intact. Furthermore, the height of the collapsed cell recorded by Braga and Ricci [52] was $160 \mathrm{~nm}$. As compared to this study, the damage observed in the present work is much more extensive as complete rupturing of the cells is seen. The height of the treated cell is very significantly reduced $(7-15 \mathrm{~nm})$ as compared to the untreated cells (450 nm). Da Silva and Teschke [43] observed that the interaction of $E$. coli with PGLa initiated with the loss of surface stiffness and the formation of micelles while in the later stages only bacterial membrane residues $(70 \mathrm{~nm})$ could be observed. Recently, AFM was used to study the antibacterial effect of chitosan [39], aqueous garlic extract [53], eugenol [40], and carvacol [50]. The present study happens to be the first one to employ AFM for elucidating the effect of LGO and LGOV on E. coli.

\section{Conclusion}

The antibacterial effect of the LGO and LGOV against $E$. coli has been investigated employing different microscopic techniques. SEM, TEM, and AFM micrographs of the LGOand LGOV-treated bacterial cells together show the evidence of rupture, cell lysis, membrane blebbing, and loss of cytoplasmic material.

Lack of details in SEM is overcome by TEM and AFM, with the latter providing vital information on the height of the cell and details of its topography. AFM and SEM examination revealed that rough surface morphology and shrinkage of the cell was apparent in the cells treated with LGO, when compared to the untreated ones. Loss of turgidity and leakage of the cytoplasm from the bacterial cells were also observed by TEM investigations. Loss of membrane integrity and damaged cell surface further supports the evidence that the mode of bactericidal action of LGOV against bacteria is through membrane disruption and further blocking of the cell growth. A further study under in vitro conditions is recommended to elaborate the antibacterial activities of LGO and LGOV for food preservation.

\section{Acknowledgments}

The present work was financially supported by CSIR SRF to $\mathrm{AKT}$ and the compilation of this work was done during 


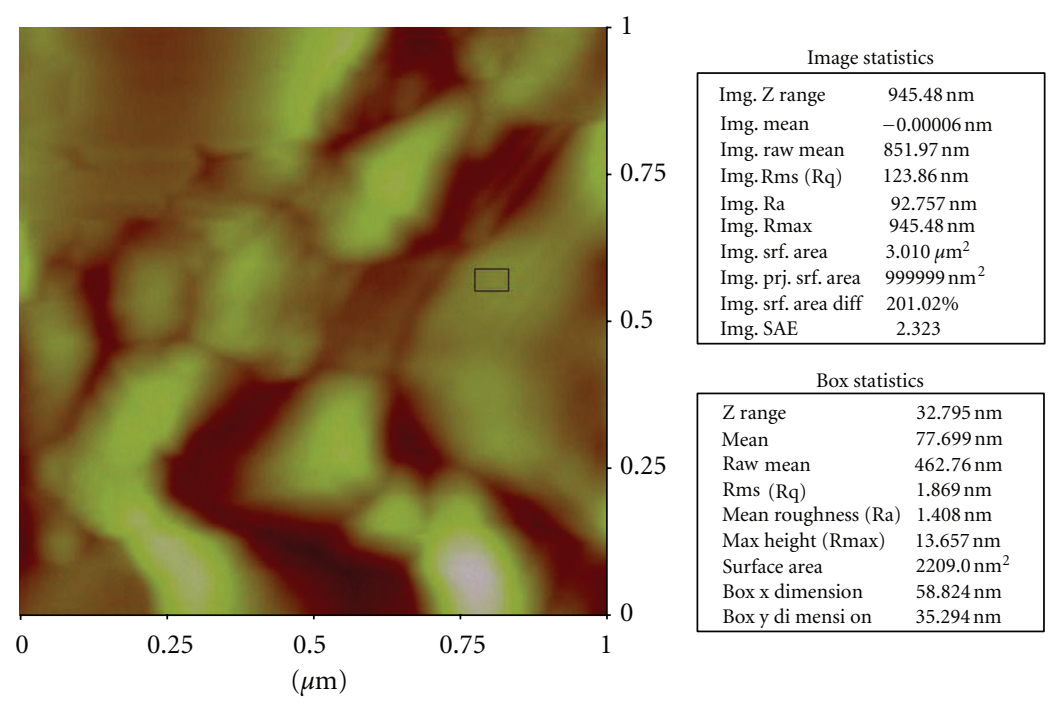

(a)
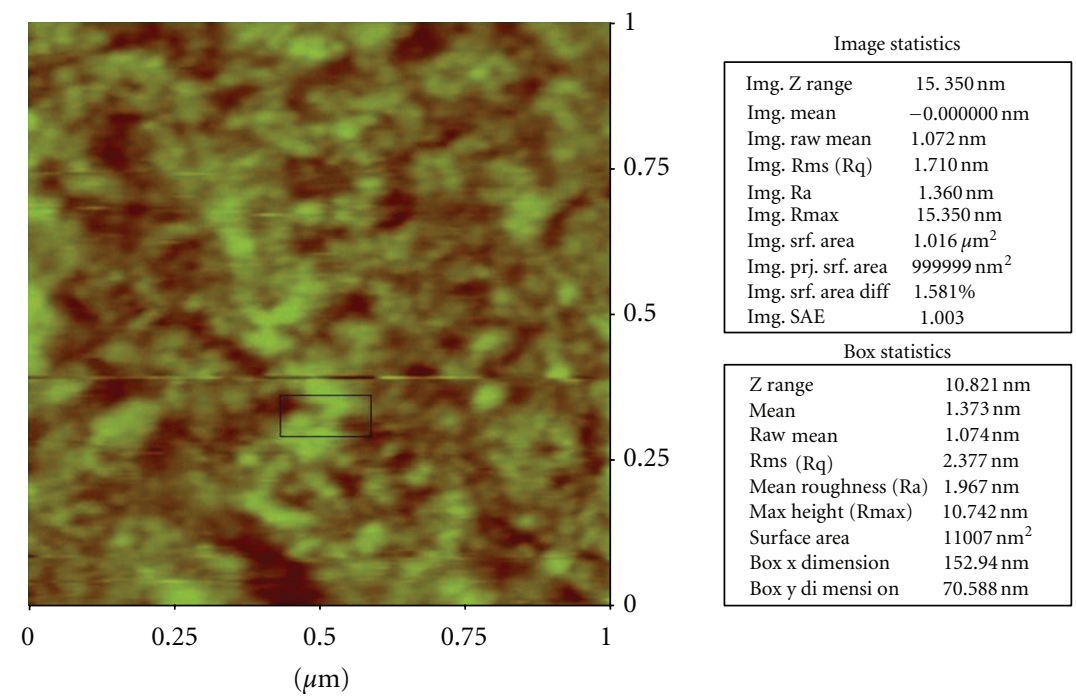

Img. SAE
\begin{tabular}{|ll|}
\hline \multicolumn{2}{|c|}{ Box statistics } \\
\hline Z range & $10.821 \mathrm{~nm}$ \\
Mean & $1.373 \mathrm{~nm}$ \\
Raw mean & $1.074 \mathrm{~nm}$ \\
Rms (Rq) & $2.377 \mathrm{~nm}$ \\
Mean roughness (Ra) & $1.967 \mathrm{~nm}$ \\
Max height (Rmax) & $10.742 \mathrm{~nm}$ \\
Surface area & $11007 \mathrm{~nm}^{2}$ \\
Box x dimension & $152.94 \mathrm{~nm}$ \\
Box y di mensi on & $70.588 \mathrm{~nm}$ \\
\hline
\end{tabular}

(b)

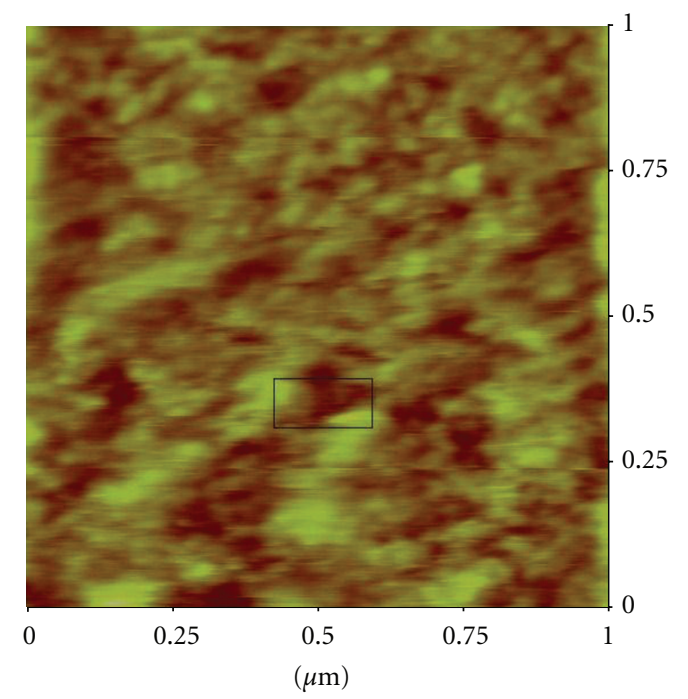

\begin{tabular}{|ll|}
\multicolumn{2}{c}{ Image statistics } \\
\hline Img. Z range & $19.597 \mathrm{~nm}$ \\
Img. mean & $-0.000001 \mathrm{~nm}$ \\
Img. raw mean & $235.45 \mathrm{~nm}$ \\
Img. Rms (Rq) & $2.219 \mathrm{~nm}$ \\
Img. Ra & $1.744 \mathrm{~nm}$ \\
Img. Rmax & $19.597 \mathrm{~nm}$ \\
Img. srf. area & $1.035 \mu \mathrm{m}^{2}$ \\
Img. prj. srf. area & $999999 \mathrm{~nm}^{2}$ \\
Img. srf. area diff & $3.483 \%$ \\
Img. SAE & 1.004 \\
\hline
\end{tabular}
Img. SAE

\begin{tabular}{|ll|}
\multicolumn{2}{c}{ Box statistics } \\
\hline Z range & $14.771 \mathrm{~nm}$ \\
Mean & $-0.329 \mathrm{~nm}$ \\
Raw mean & $246.37 \mathrm{~nm}$ \\
Rms (Rq) & $3.327 \mathrm{~nm}$ \\
Mean roughness (Ra) & $2.784 \mathrm{~nm}$ \\
Max height (Rmax) & $14.914 \mathrm{~nm}$ \\
Surface area & $15142 \mathrm{~nm}^{2}$ \\
Box x dimension & $168.30 \mathrm{~nm}$ \\
Box y di mensi on & $84.149 \mathrm{~nm}$ \\
\hline
\end{tabular}

(c)

Figure 4: Continued. 


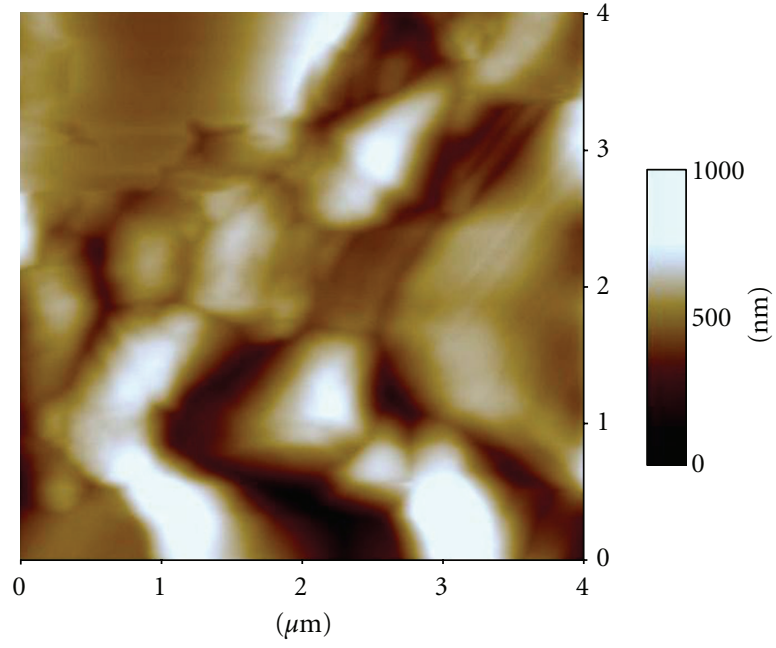

(d)

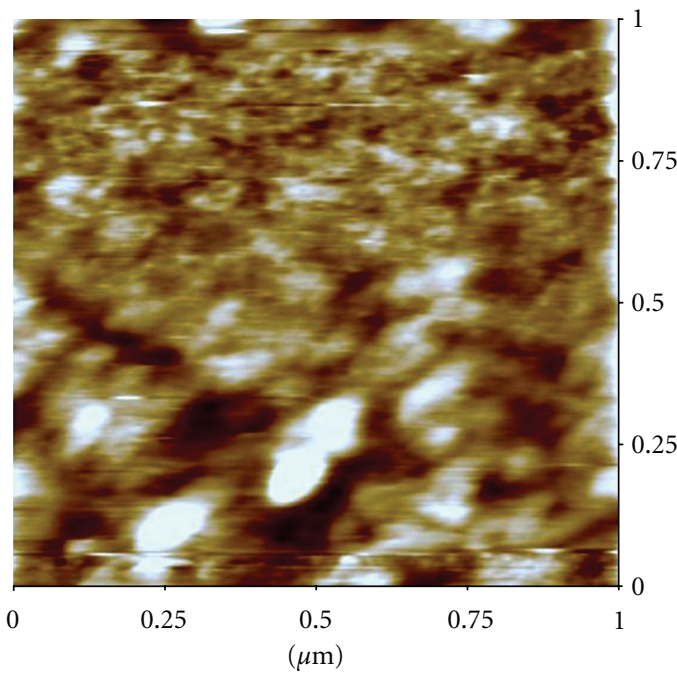

(f)

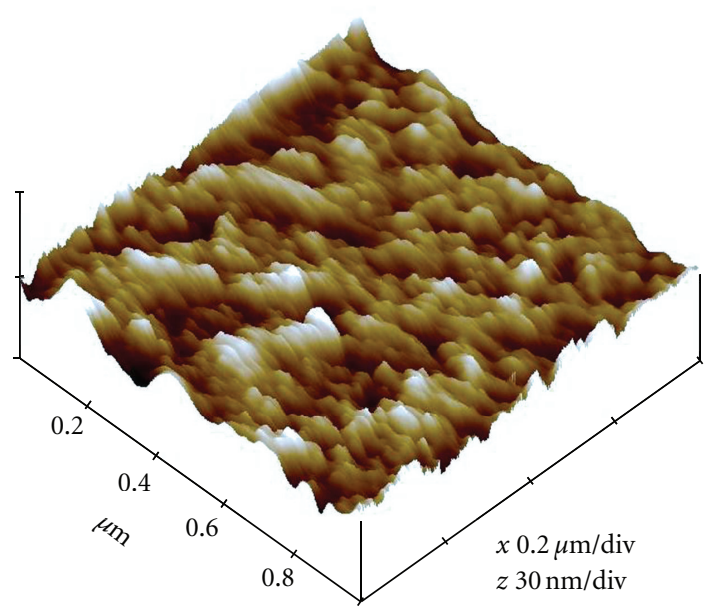

(h)

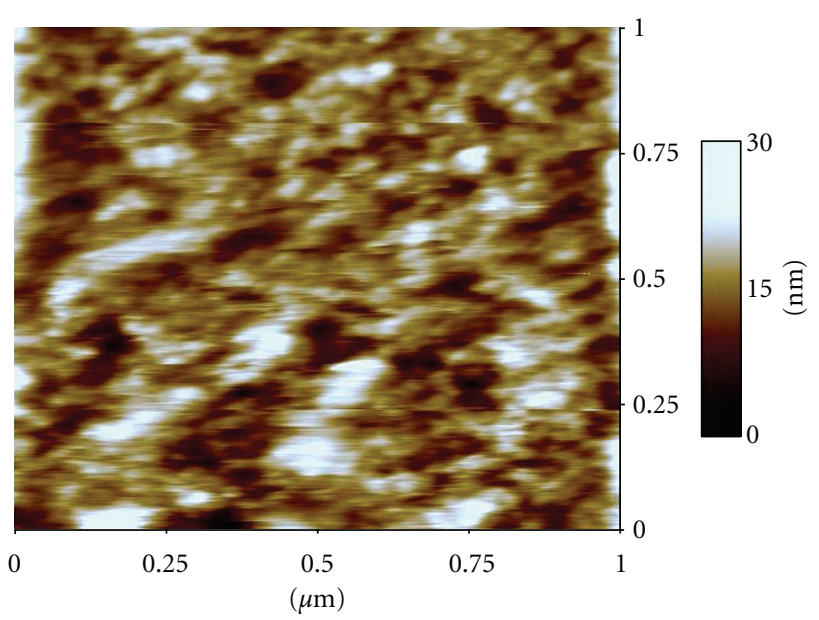

(e)

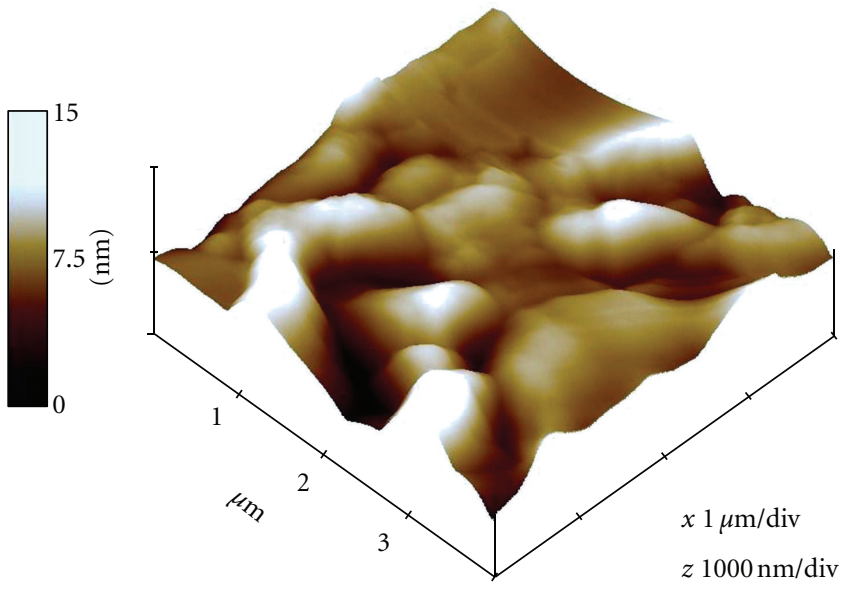

(g)

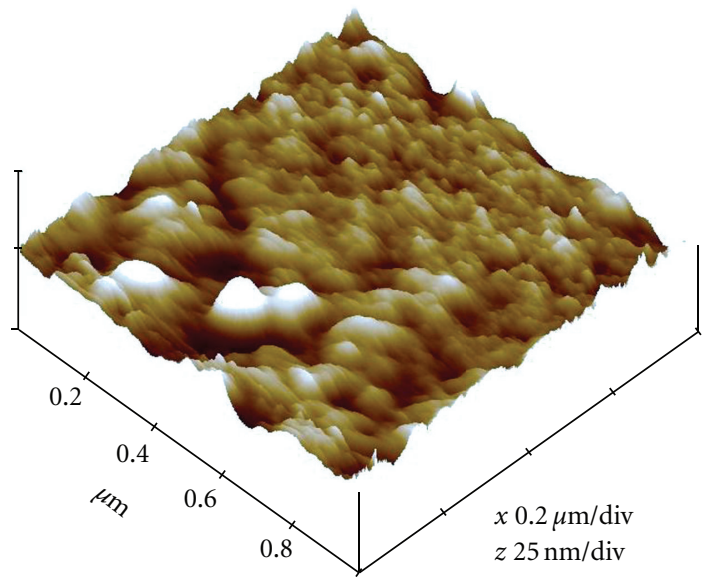

(i)

FIGURE 4: Atomic force micrographs showing variation in image statistics, height, and three-dimensional view of untreated, LGO-treated and LGOV-treated E. coli cells. (a) The root mean square values and surface area difference of untreated E. coli cells (rms $1.86 \mathrm{~nm}$, sad $201.02 \%$ ). (b) LGO-treated ( $\mathrm{rms} 2.33 \mathrm{~nm}$, sad 1.58\%). (c) LGOV-treated (rms $3.32 \mathrm{~nm}$, sad 3.48\%). (d) Height of the untreated E. coli cells from the glass surface $(\mathrm{h} 450 \mathrm{~nm})$. (e) LGO-treated (h $14 \mathrm{~nm}$ ). (f) LGOV-treated (h $7 \mathrm{~nm})$. (g) Z-axis value for three-dimensional structure of untreated E. coli cells ( $z 1000 \mathrm{~nm} /$ div). (h) LGO-treated $(z 30 \mathrm{~nm} /$ div). (i) LGOV-treated $(z 25 \mathrm{~nm} /$ div). 


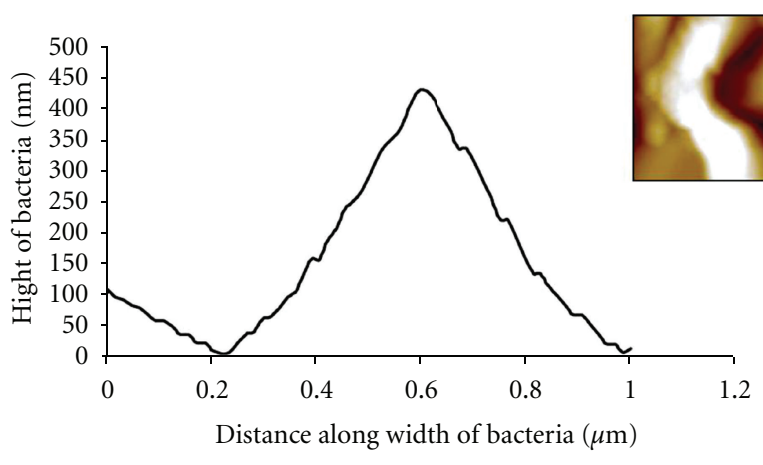

(a)

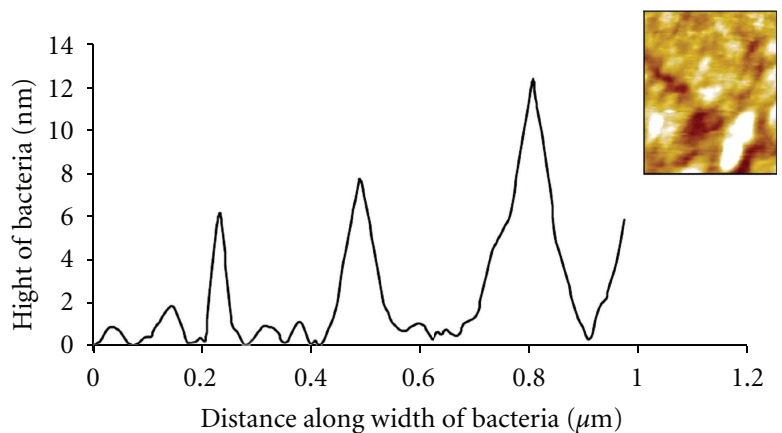

(b)

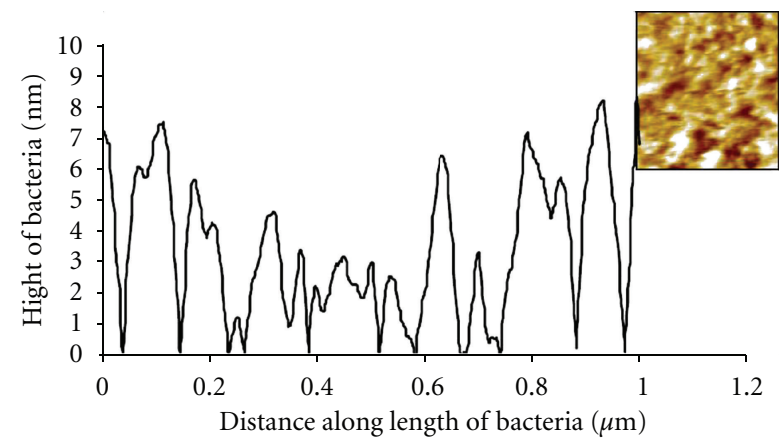

(c)

Figure 5: Graphical representation of atomic force microscopy results showing variation in height of E. coli cell along the width. (a) Untreated smooth cells (h $450 \mathrm{~nm}$ ), (b) LGO-treated shrunken cells (h $14 \mathrm{~nm}$ ). (c) LGOV-treated ruptured cells (h $7 \mathrm{~nm}$ ).

India4EU (EMECW13c) research exchange fellowship to A. K. Tyagi. The authors wish to thank Professor B. R. Mehta (IIT Delhi) and Dr. C. Singh (IIT Delhi) for providing AFM and SEM facilities. Dr. Deepak (IIT Delhi) and Mr. D. C. Sharma (IIT Delhi) are also acknowledged for their kind technical support in AFM and SEM, respectively.

\section{References}

[1] H. Chu, "Germany searches for source of food contamination," Los Angeles Times, http://www.sfgate.com/cgi-bin/ article.cgi?f=/c/a/2011/06/01/MNME1JOB0U.DTL\#ixzz1OicnY5yE, 2011.

[2] A. Martin and L. Beutin, "Characteristics of Shiga toxinproducing Escherichia coli from meat and milk products of different origins and association with food producing animals as main contamination sources," International Journal of Food Microbiology, vol. 146, no. 1, pp. 99-104, 2011.

[3] J. L. Platell, J. R. Johnson, R. N. Cobbold, and D. J. Trott, "Multidrug-resistant extraintestinal pathogenic Escherichia coli of sequence type ST131 in animals and foods," Veterinary Microbiology, vol. 153, no. 1-2, pp. 99-108, 2011.

[4] A. I. Hussain, F. Anwar, P. S. Nigam et al., "Antibacterial activity of some Lamiaceae essential oils using resazurin as an indicator of cell growth," LWT-Food Science and Technology, vol. 44, no. 4, pp. 1199-1206, 2011.

[5] J. Weiss, S. Gaysinksy, M. Davidson, and J. McClements, "Nanostructured encapsulation systems: food antimicrobials," in IUFoST World Congress Book: Global Issues in Food Science and Technology, G. V. Barbosa-Cánovas, A. Mortimer, D.
Lineback, W. Spiess, and K. Buckle, Eds., pp. 425-479, Elsevier, Amsterdam, The Netherlands, 2009.

[6] A. Govaris, E. Botsoglou, D. Sergelidis, and P. S. Chatzopoulou, "Antibacterial activity of oregano and thyme essential oils against Listeria monocytogenes and Escherichia coli O157:H7 in feta cheese packaged under modified atmosphere," LWT-Food Science and Technology, vol. 44, no. 4, pp. 1240-1244, 2011.

[7] X. Chen, Y. Zhang, Y. Zu, Y. Fu, and W. Wang, "Composition and biological activities of the essential oil from Schisandra chinensis obtained by solvent-free microwave extraction," LWT-Food Science and Technology, 2011.

[8] V. Hulin, A. G. Mathot, P. Mafart, and L. Dufossé, "Antimicrobial properties of essential oils and flavour compounds," Sciences des Aliments, vol. 18, no. 6, pp. 563-582, 1998.

[9] S. Burt, "Essential oils: their antibacterial properties and potential applications in foods-a review," International Journal of Food Microbiology, vol. 94, no. 3, pp. 223-253, 2004.

[10] A. I. Nazer, A. Kobilinsky, J. L. Tholozan, and F. DuboisBrissonnet, "Combinations of food antimicrobials at low levels to inhibit the growth of Salmonella sv. Typhimurium: a synergistic effect?" Food Microbiology, vol. 22, no. 5, pp. 391398, 2005.

[11] A. K. Tyagi and A. Malik, "Antimicrobial potential and chemical composition of Eucalyptus globulus oil in liquid and vapour phase against food spoilage microorganisms," Food Chemistry, vol. 126, no. 1, pp. 228-235, 2011.

[12] A. K. Tyagi and A. Malik, "Antimicrobial potential and chemical composition of Mentha piperita oil in liquid and vapour phase against food spoiling microorganisms," Food Control, vol. 22, no. 11, pp. 1707-1714, 2011. 
[13] P. López, C. Sánchez, R. Batlle, and C. Nerín, "Development of flexible antimicrobial films using essential oils as active agents," Journal of Agricultural and Food Chemistry, vol. 55, no. 21, pp. 8814-8824, 2007.

[14] F. Donsì, M. Annunziata, M. Sessa, and G. Ferrari, "Nanoencapsulation of essential oils to enhance their antimicrobial activity in foods," LWT-Food Science and Technology, vol. 44, no. 9, pp. 1908-1914, 2011.

[15] A. K. Tyagi and A. Malik, "Liquid and vapour-phase antifungal activities of selected essential oils against candida albicans: microscopic observations and chemical characterization of cymbopogon citratus," BMC Complementary and Alternative Medicine, vol. 10, p. 65, 2010.

[16] H. J. Butt, E. K. Wolff, S. A. C. Gould, B. Dixon Northern, C. M. Peterson, and P. K. Hansma, "Imaging cells with the atomic force microscope," Journal of Structural Biology, vol. 105, no. $1-3$, pp. 54-61, 1990.

[17] G. Binnig, C. F. Quate, and C. Gerber, "Atomic force microscope,” Physical Review Letters, vol. 56, no. 9, pp. 930-933, 1986.

[18] P. E. Milhiet, P. Dosset, M. C. Giocondi, and C. Le Grimellec, "Atomic force microscopy: from cell imaging to molecular manipulation," Journal de la Societe de Biologie, vol. 198, no. 2, pp. 169-174, 2004.

[19] C. J. Sullivan, J. L. Morrell, D. P. Allison, and M. J. Doktycz, "Mounting of Escherichia coli spheroplasts for AFM imaging," Ultramicroscopy, vol. 105, no. 1-4, pp. 96-102, 2005.

[20] A. V. Bolshakova, O. I. Kiselyova, A. S. Filonov, O. Y. Frolova, Y. L. Lyubchenko, and I. V. Yaminsky, "Comparative studies of bacteria with an atomic force microscopy operating in different modes," Ultramicroscopy, vol. 86, no. 1-2, pp. 121$128,2001$.

[21] M. J. Doktycz, C. J. Sullivan, P. R. Hoyt, D. A. Pelletier, S. $\mathrm{Wu}$, and D. P. Allison, "AFM imaging of bacteria in liquid media immobilized on gelatin coated mica surfaces," Ultramicroscopy, vol. 97, no. 1-4, pp. 209-216, 2003.

[22] P. Schaer-Zammaretti and J. Ubbink, "Imaging of lactic acid bacteria with AFM-elasticity and adhesion maps and their relationship to biological and structural data," Ultramicroscopy, vol. 97, no. 1-4, pp. 199-209, 2003.

[23] Y. F. Dufrêne, "Application of atomic force microscopy to microbial surfaces: from reconstituted cell surface layers to living cells," Micron, vol. 32, no. 2, pp. 153-165, 2001.

[24] M. Meincken, D. L. Holroyd, and M. Rautenbach, "Atomic force microscopy study of the effect of antimicrobial peptides on the cell envelope of Escherichia coli," Antimicrobial Agents and Chemotherapy, vol. 49, no. 10, pp. 4085-4092, 2005.

[25] M. Gad, A. Itoh, and A. Ikai, "Mapping cell wall polysaccharides of living microbial cells using atomic force microscopy," Cell Biology International, vol. 21, no. 11, pp. 697-706, 1997.

[26] A. N. Devkatte, G. B. Zore, and S. M. Karuppayil, "Potential of plant oils as inhibitors of Candida albicans growth," FEMS Yeast Research, vol. 5, no. 9, pp. 867-873, 2005.

[27] NCCLS- National Committee for Clinical Laboratory Standards, Methods for determining Bacterial Activity of Antimicrobial Agents, NCCLS, Wayne, Pa, USA, 1999.

[28] P. López, C. Sánchez, R. Batlle, and C. Nerín, "Solid- and vapor-phase antimicrobial activities of six essential oils: susceptibility of selected foodborne bacterial and fungal strains," Journal of Agricultural and Food Chemistry, vol. 53, no. 17, pp. 6939-6946, 2005.

[29] A. K. Tyagi and A. Malik, "Antimicrobial action of essential oil vapours and negative air ions against Pseudomonas fluorescens," International Journal of Food Microbiology, vol. 143, no. 3, pp. 205-210, 2010.

[30] M. I. Naik, B. A. Fomda, E. Jaykumar, and J. A. Bhat, "Antibacterial activity of lemongrass (Cymbopogon citratus) oil against some selected pathogenic bacterias," Asian Pacific Journal of Tropical Medicine, vol. 3, no. 7, pp. 535-538, 2010.

[31] M. Oussalah, S. Caillet, L. Saucier, and M. Lacroix, "Inhibitory effects of selected plant essential oils on the growth of four pathogenic bacteria: E. coli O157:H7, Salmonella Typhimurium, Staphylococcus aureus and Listeria monocytogenes," Food Control, vol. 18, no. 5, pp. 414-420, 2007.

[32] K. Vagionas, K. Graikou, O. Ngassapa, D. Runyoro, and I. Chinou, "Composition and antimicrobial activity of the essential oils of three Satureja species growing in Tanzania," Food Chemistry, vol. 103, no. 2, pp. 319-324, 2007.

[33] M. C. T. Duarte, E. E. Leme, C. Delarmelina, A. A. Soares, G. M. Figueira, and A. Sartoratto, "Activity of essential oils from Brazilian medicinal plants on Escherichia coli," Journal of Ethnopharmacology, vol. 111, no. 2, pp. 197-201, 2007.

[34] F. Maggi, C. Cecchini, A. Cresci et al., "Chemical composition and antimicrobial activity of the essential oil from Ferula glauca L. (F. communis L. subsp. glauca) growing in Marche (central Italy)," Fitoterapia, vol. 80, no. 1, pp. 68-72, 2009.

[35] S. Inouye, K. Uchida, and S. Abe, "Vapor activity of 72 essential oils against a Trichophyton mentagrophytes," Journal of Infection and Chemotherapy, vol. 12, no. 4, pp. 210-216, 2006.

[36] K. I. Suhr and P. V. Nielsen, "Antifungal activity of essential oils evaluated by two different application techniques against rye bread spoilage fungi," Journal of Applied Microbiology, vol. 94, no. 4, pp. 665-674, 2003.

[37] A.K. Tyagi and A. Malik, "Bactericidal action of lemon grass oil vapors and negative air ions," Innovative Food Science and Emerging Technologies, vol. 13, pp. 169-177, 2012.

[38] S. Inouye, Y. Nishiyama, K. Uchida, Y. Hasumi, H. Yamaguchi, and S. Abe, "The vapor activity of oregano, perilla, tea tree, lavender, clove, and geranium oils against a Trichophyton mentagrophytes in a closed box," Journal of Infection and Chemotherapy, vol. 12, no. 6, pp. 349-354, 2006.

[39] P. Eaton, J. C. Fernandes, E. Pereira, M. E. Pintado, and F. Xavier Malcata, "Atomic force microscopy study of the antibacterial effects of chitosans on Escherichia coli and Staphylococcus aureus," Ultramicroscopy, vol. 108, no. 10, pp. 1128-1134, 2008.

[40] K. P. Devi, S. A. Nisha, R. Sakthivel, and S. K. Pandian, "Eugenol (an essential oil of clove) acts as an antibacterial agent against Salmonella typhi by disrupting the cellular membrane," Journal of Ethnopharmacology, vol. 130, no. 1, pp. 107$115,2010$.

[41] M. J. Park, K. S. Gwak, I. Yang et al., "Effect of citral, eugenol, nerolidol and $\alpha$-terpineol on the ultrastructural changes of Trichophyton mentagrophytes," Fitoterapia, vol. 80, no. 5, pp. 290-296, 2009.

[42] P. C. Braga and D. Ricci, "Atomic force microscopy: application to investigation of Escherichia coli morphology before and after exposure to cefodizime," Antimicrobial Agents and Chemotherapy, vol. 42, no. 1, pp. 18-22, 1998.

[43] A. Da Silva and O. Teschke, "Dynamics of the antimicrobial peptide PGLa action on Escherichia coli monitored by atomic force microscopy," World Journal of Microbiology and Biotechnology, vol. 21, no. 6-7, pp. 1103-1110, 2005.

[44] I. Sondi and B. Salopek-Sondi, "Silver nanoparticles as antimicrobial agent: a case study on E. coli as a model for Gramnegative bacteria," Journal of Colloid and Interface Science, vol. 275, no. 1, pp. 177-182, 2004. 
[45] S. M. Yi, J. L. Zhu, L. L. Fu, and J. R. Li, "Tea polyphenols inhibit Pseudomonas aeruginosa through damage to the cell membrane," International Journal of Food Microbiology, vol. 144, no. 1, pp. 111-117, 2010.

[46] H. Liu, Y. Du, X. Wang, and L. Sun, "Chitosan kills bacteria through cell membrane damage," International Journal of Food Microbiology, vol. 95, no. 2, pp. 147-155, 2004.

[47] J. A. Castillo, P. Clapés, M. R. Infante, J. Comas, and Á. Manresa, "Comparative study of the antimicrobial activity of bis( $\mathrm{N} \alpha$-caproyl-L-arginine)-1,3-propanediamine dihydrochloride and chlorhexidine dihydrochloride against Staphylococcus aureus and Escherichia coli," Journal of Antimicrobial Chemotherapy, vol. 57, no. 4, pp. 691-698, 2006.

[48] M. Cristani, M. D’Arrigo, G. Mandalari et al., "Interaction of four monoterpenes contained in essential oils with model membranes: implications for their antibacterial activity," Journal of Agricultural and Food Chemistry, vol. 55, no. 15, pp. 6300-6308, 2007.

[49] I. M. Helander, H. L. Alakomi, K. Latva-Kala et al., "Characterization of the action of selected essential oil components on gram-negative bacteria," Journal of Agricultural and Food Chemistry, vol. 46, no. 9, pp. 3590-3595, 1998.

[50] A. La Storia, D. Ercolini, F. Marinello, R. Di Pasqua, F. Villani, and G. Mauriello, "Atomic force microscopy analysis shows surface structure changes in carvacrol-treated bacterial cells," Research in Microbiology, vol. 162, no. 2, pp. 164-172, 2011.

[51] D. Trombetta, F. Castelli, M. G. Sarpietro et al., "Mechanisms of antibacterial action of three monoterpenes," Antimicrobial Agents and Chemotherapy, vol. 49, no. 6, pp. 2474-2478, 2005.

[52] P. C. Braga and D. Ricci, "Atomic force microscopy: application to investigation of Escherichia coli morphology before and after exposure to cefodizime," Antimicrobial Agents and Chemotherapy, vol. 42, no. 1, pp. 18-22, 1998.

[53] C. C. Perry, M. Weatherly, T. Beale, and A. Randriamahefa, "Atomic forcemicroscopy study of the antimicrobial activity of aqueous garlic versus ampicillin against Escherichia coli and Staphylococcus aureus," Journal of the Science of Food and Agriculture, vol. 89, no. 6, pp. 958-964, 2009. 


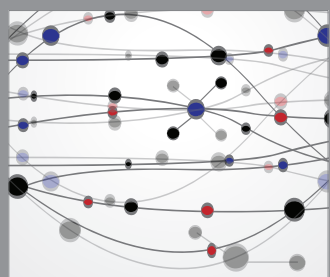

The Scientific World Journal
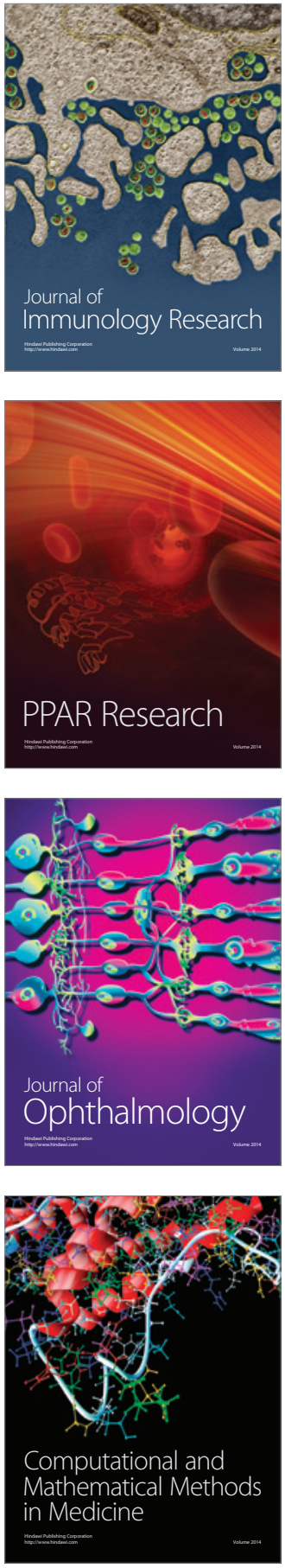

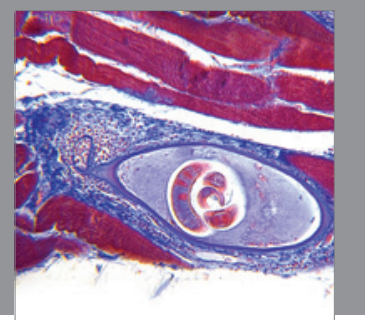

Gastroenterology

Research and Practice
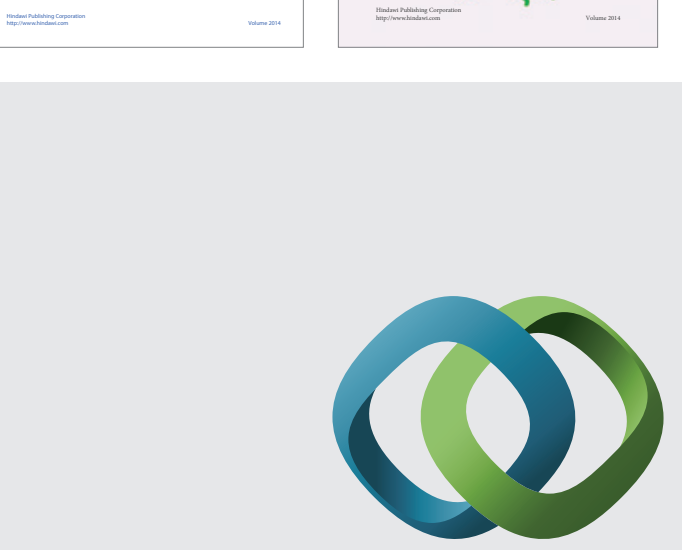

\section{Hindawi}

Submit your manuscripts at

http://www.hindawi.com
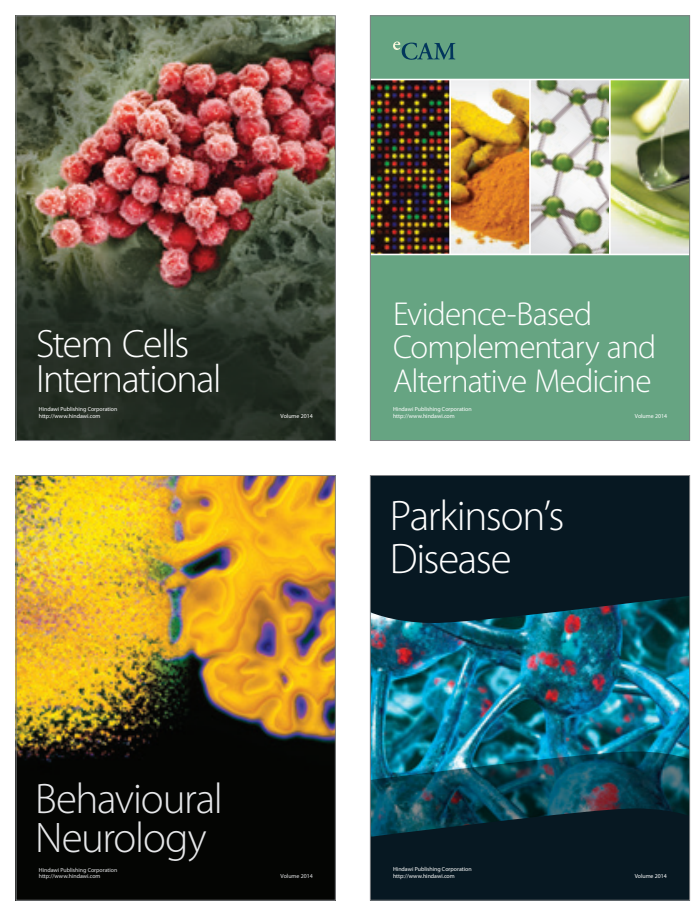

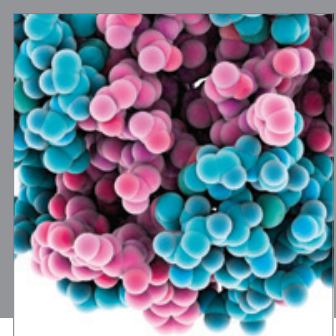

Journal of
Diabetes Research

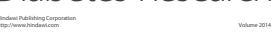

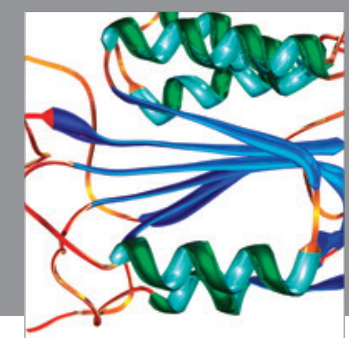

Disease Markers
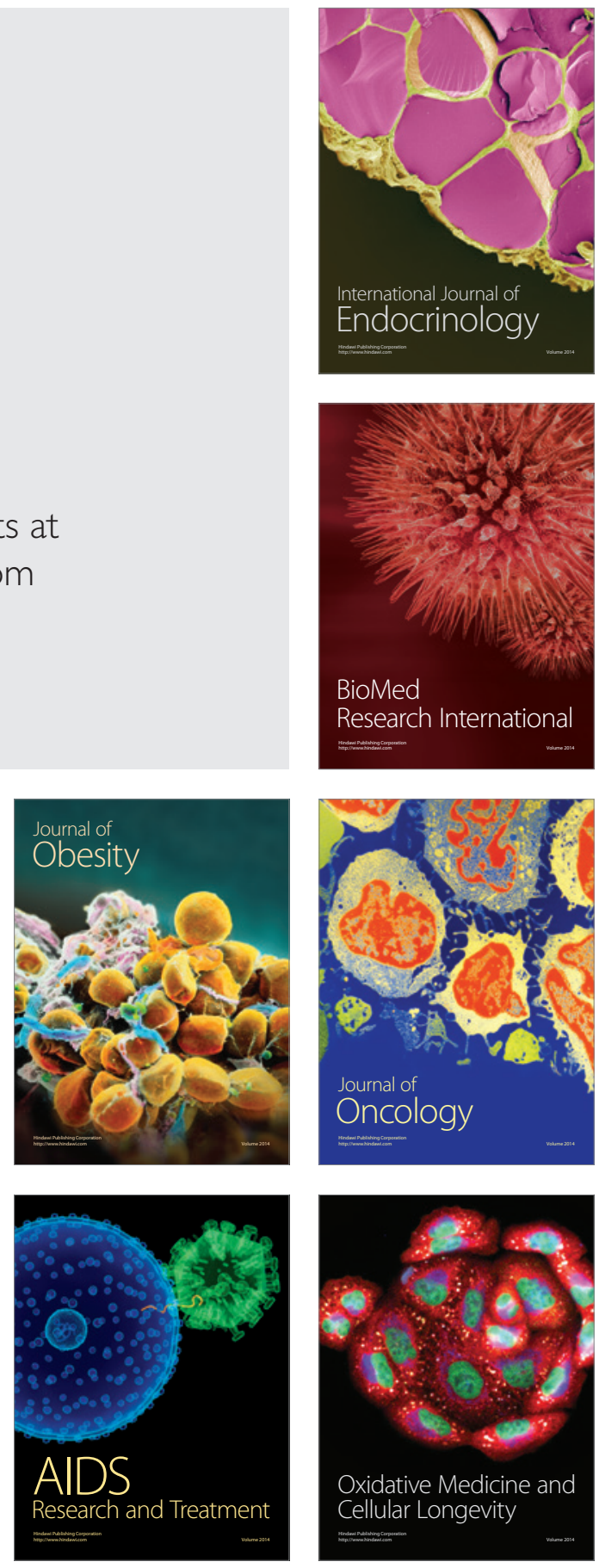